\title{
The Blind Justice Paradox: Judges with Visual Impairments and the Disability Metaphor
}

\author{
Doron Dorfman
}

\begin{abstract}
The metaphor connecting blindness and fair-impartial legal treatment has been embodied in the Western world for hundreds of years through the image of a blindfolded woman who represents justice. Nonetheless, not much has been written about the complexities and obstacles that stand in the way of placing actual blind judges on the bench. Nor has the 'Icon of Justice' been used to represent the social struggle for disability rights. This article is the first to turn a spotlight on the long history of blind people in England and the United States serving as members of the judiciary and to explore how this integration dovetails with the symbolic importance of blindness in the iconography of law. The article delves into the varied connotations of blindness throughout Western culture and legal history, specifically in its purported relationship to the objectivity of the judge. Finally, the article contrasts examples of the inclusion of blind people in Anglo-American legal systems with an Israeli case, revealing existing barriers that still prevent many blind people from entering the legal profession.
\end{abstract}

\section{Keywords}

Judges, Judicial Appointment, Disability, Disability Employment, Law and Humanities, Art and Law, Legal History, Comparative Law

\section{Introduction}

In late December 2014, Richard Bernstein made history as he was sworn in as the first blind person to serve on Michigan's highest court. ${ }^{1}$ Bernstein's election

* Bradley Fellow at the Stanford Constitutional Law Center; Graduate Fellow at the McCoy Family Center for Ethics in Society at Stanford University; Perla and Samuel Rubinstein fellow at Alin Beit Noam Institute for Disability Studies; JSD Candidate at Stanford Law School. I would like to thank Susan Schweik, Justice Richard Bernstein, Leora Dahan-Katz, Noam Kuperstein, Asaf Kletter, Sophie Hagen, Emily Polk and the anonymous reviewer for their insightful comments and suggestions.

1 Jacob Gershman, 'Richard Bernstein Brings "Blind Justice" to Michigan's Highest Court' The Wall Street Journal (New York, 29 December 2014) <http://on.wsj.com/1y1ARbg> accessed 9 August 2016. 
is emblematic of the integration of blind persons into symbolic judicial positions in Anglo-American legal systems. This article is the first to turn a spotlight on the long history of blind persons in England ${ }^{2}$ and the United States (US) serving as members of the judiciary and to explore how this integration dovetails with the symbolic importance of blindness in the iconography of the legal system. The article delves into the varied connotations of blindness throughout Western culture and legal history, specifically in its purported relationship to the objectivity of the judge. Finally, the article contrasts examples of the inclusion of blind people in the Anglo-American legal systems with an Israeli legal case. A close examination of these case studies reveals the barriers that remain for individuals with visual impairments who want to enter the legal profession and the beliefs about disability that reinforce these obstacles.

The possibility of a blind individual serving in a judicial position in Israel first presented itself in 2005, when the case of Amidar v Hai came before the Tel Aviv District Court. ${ }^{3}$ An arbitrator in the case went blind while adjudicating it; she was then faced with a request, formally submitted to the court by one of the parties, to disqualify her based on the argument that her disability would prevent her from doing her job. Judge Rina Meshel of the Tel Aviv District Court dismissed the request, delivering an impassioned, advanced argument for the ability of a blind person to serve in a judicial position, specifically on the Israeli bench. However, Judge Meshel's argument was ignored once the case first reached the Israeli Supreme Court. ${ }^{4}$ Presented with the rare opportunity to change common perceptions of the ability of blind persons to hold key roles in Israeli society, the Court failed to rise to the occasion. Although the Court ultimately supported the right of the arbitrator to stay in her role, once the case reached it for the second time, ${ }^{5}$ the decision failed to address the complex processes of societal stigmatisation experienced by those as well, but since all the examples I use are from England and because the particularities of differences between the British and English systems do not matter to the project, I will refer only to the English system. DC (TA) 23342/04 Amidar-National Co for Immigrant Housing Ltd v Hai 2002 (2) 664 (2005) (Isr) (DC Amidar).

4 CA 10487/07 Amidar-National Co for Immigrant Housing Ltd v Hai (5 May 2010), Nevo Legal Database (by subscription) (Isr) (CA Amidar).

5 CA 6931/11 Amidar-National Co for Immigrant Housing Ltd v Hai (10 November 2011), Nevo Legal Database (by subscription) (Isr) (CA Amidar 2011). 
living with disabilities-processes acknowledged by numerous legal judgments and theoretical texts associated with the field of disability studies.

Disability studies is a relatively new field that is gaining momentum in academia and beyond. ${ }^{6}$ This field aims to study disability as a social, cultural, and political phenomenon across settings and disciplines. ${ }^{7}$ Disability studies is based on the premise that disability is socially constructed rather than purely a medicalpathological phenomenon that is intrinsic to the individual. This idea underlined the social model of disability that was developed in the early 1970s. This model elucidated the complex processes by which people with disabilities are stigmatised and consequently excluded and discriminated against by society. Further research and the theoretical development of the social model led to the understanding of disability as a complex and fluid phenomenon that 'encompasses a wide range of bodily, cognitive and sensory differences and capacities', yet 'is produced as much by environmental and social factors as it is by bodily functions."

A disability rights critique of the law can be identified as early as the mid-1960s in the writings of Jacobus tenBroek, one of the founders of the US disability rights movement and the founder and president of the American National Federation of the Blind. ${ }^{9}$ Yet only in 2006 was a new field called disability legal studies, which infused the disability studies perspective into legal scholarship and practice, officially introduced by Israeli legal scholar Sagit Mor. ${ }^{10}$ This work contributes to the field of disability legal studies by investigating the role that courts, legal actors

Cecilia Capuzzi Simon, 'Disability Studies: A New Normal' The New York Times (New York, 1 November 2013) <http://www.nytimes.com/2013/11/03/education/edlife/disability-studiesa-new-normal.html?_r=0> accessed 9 August 2016; In August 2016, The New York Times initiated a series of stories on disability, written by disability studies scholars and people with disabilities. The first story by renowned disability studies scholar Rosemarie GarlandThomson, touching on key concepts in the field such as disability, culture and identity, was published on 19 August 2016. See Rosemarie Garland-Thomson, 'Becoming Disabled' The New York Times (New York, 19 August 2016) <http://www.nytimes.com/2016/08/21/opinion/ sunday/becoming-disabled.html?smid=fb-share\&_r=0 $>$ accessed 22 August 2016.

7 Simi Linton, 'What Is Disability Studies?' (2005) 120 PMLA 518, 518; Sagit Mor, 'Between Charity, Welfare, and Warfare: A Disability Legal Studies Analysis of Privilege and Neglect in Israeli Disability Policy' (2006) 18 Yale J L \& the Human 63, 64; Dan Goodley, Disability Studies: An Interdisciplinary Introduction (SAGE Publications 2010) xi. Rachel Adams, Benjamin Reiss and David Serlin, 'Disability' in Rachel Adams, Benjamin Reiss and David Serlin (eds), Keywords for Disability Studies (New York UP 2015) 5-6.

9 Jacobus tenBroek, 'The Right to Live in the World: The Disabled in the Law of Torts' (1966) 54 California L Rev.

10 Mor (n 7) 67-68; Arlene S Kanter, 'The Law: What's Disability Studies Got to Do With It or an Introduction to Disability Legal Studies' (2011) 42 Colum Hum Rts L Rev 403, 426-28. 
and legal iconography play in the social construction of blindness inside and outside the courthouse.

This article also addresses the varied concepts and iconographies of 'blind justice' in Western societies and legal systems and draws connections between these metaphorical narratives and the appearance of literal, physical disability in the legal system. On the one hand, the image of a blindfolded woman holding a sword in one hand and scales in the other, to whom I refer as the 'Icon of Justice', represents the law's declared aspiration that judges achieve 'metaphoric blindness' with regard to those characteristics of the litigants that are irrelevant to the essence of the dispute or offence. On the other hand, Western society generally considers physical blindness to be a debilitating disability that prevents the blind person from performing a wide range of tasks and from serving, de facto, in a wide range of professional positions. I term this ambivalent attitude towards blindness in the legal sphere as the Blind Justice Paradox. Through an analysis of American, English, and Israeli case studies and examples, as well as the theoretical and representational basis on which their respective approaches to disability and blindness are founded, this article demonstrates the ways in which physical realities intrude upon the iconographical basis for societal imaginings of rationality and difference. Far from merely serving as a theoretical exercise, this article seeks not only to shed light on the contradictions in legal approaches to metaphoric and literal blindness, but also to advance the discourse regarding the rights of people with disabilities and to help alter stereotypes regarding their abilities and skills. By presenting facts from the actual historical records relating to representations of blindness in the legal systems of the West, this article forms part of a larger movement to promote the integration of blind persons into key roles in society.

The article is divided into three main sections: In the first section, I analyse the term 'blind justice' as it is presented through the symbol of the 'icon of Justice', including a discussion of the sociocultural associations with blindness throughout history as they appear in literature and folklore. This reveals the many, often contradictory approaches of the legal system toward blindness as imagery and as disability. In the second section, I present examples of the successful integration of blind judges into the English and American legal systems, and I trace its history back to the eighteenth century. I also discuss the social model of disability and, through it, the barriers that still exist in incorporating blind persons into the legal market and the judiciary. In the third section, I analyse the Tel Aviv District Court's judgment in the matter of Amidar v Hai: a brave approach that constitutes, in my opinion, a first step in paving the way for blind Israelis to fill judicial or quasi-judicial positions. I then present the Israeli Supreme Court's judgment in the 
same matter, and demonstrate how it could have done better to promote a positive discourse surrounding the integration of blind persons into the Israeli legal system.

\section{Socio-Cultural Aspects of 'Blind Justice'}

\subsection{The Ambiguity of the Icon of Justice}

Throughout most of Western civilisation's history, 'justice' has been personified as a large woman, depicted in the nude or in a traditional Greek toga, bearing a series of symbolic objects. The most commonly recognised of these objects are the sword, the scales, and the blindfold, which in some depictions covers her eyes completely and in others has been pierced with holes that allow her to see through it. $^{11}$ The image of this intriguing woman-a religious, cultural and political iconcan be found in courts, town squares, law schools, and public buildings throughout Western Europe and the US, as well as in works of visual art, books, films, and other cultural products. $^{12}$

Interestingly, this woman is one of many icons, mostly female, who symbolise abstract, philosophically important concepts. None of them, however, seem to have lingered in public consciousness more than the woman who represents justice. ${ }^{13}$ One possible explanation is that, over the course of history, Western sovereigns and governments have sought to associate themselves with the virtue of justice, taking pains to incorporate it visibly into their core societal institutions and maintain a connection with it in the public's awareness. ${ }^{14}$

Among the objects surrounding various images of the Icon of Justice are a bundle of wooden sticks and an axe (fasces) - which historically symbolised the Roman Republic and the legal system - and a curved goat's horn overflowing with fruits and grains (cornucopia) - a symbol of wealth and food in ancient Greece and Rome. See Dennis E Curtis and Judith Resnik, 'Images of Justice' (1987) 96 Yale LJ 1727, 1741-43. ibid; For recent examples of the use of the Icon of Justice in cultural products see Judith Resnik and Dennis Curtis, Representing Justice: Invention, Controversy, and Rights in City-States and Democratic Courtrooms (Yale UP 2011) 1-8.

13 The image of the Icon of Justice first appeared in the Middle Ages together with six other female icons representing basic virtues and qualities: intelligence, restraint, courage, faith, hope and generosity: Curtis and Resnik (n 11) 1729-31; Resnik and Curtis (n 12) 10.

14 It could be argued as well that the iconography of justice was used as visual justification for violence and strict measures on the part of sovereigns against their subjects. The other virtues, presented through other icons, were not as crucial for maintaining order and authority: Curtis and Resnik (n 11) 1734; Resnik and Curtis (n 12) 12. 
The Icon of Justice image has gone through many transformations and has been linked to the religious iconography of various cultures (including Egyptian, Greek, and Roman mythology, as well as the New Testament); however, the objects surrounding the Icon are almost entirely consistent across manifestations. ${ }^{15}$ The aspect of the Icon of Justice that is often characterised as the 'most mysterious and challenging' is the woman's blindfold, on which I choose to focus. This blindfold and the state of forced blindness that it imposes are, interestingly, absent from the Icon's first incarnations. Thus, for example, coins in circulation during the reign of the Roman emperor Tiberius (who ruled from 14 to $37 \mathrm{CE}$ ) feature a woman holding a sword and scales with eyes uncovered. Similarly, artefacts from the Middle Ages depict the Icon with her eyes wide open. The blindfold began appearing on the Icon of Justice in the fifteenth century. This has encouraged many contemporary scholars to contemplate the nature of this forced blindness and its symbolism. ${ }^{16}$

In contemporary Western culture and art, blindness is treated ambivalently: on the one hand, it is perceived as a disability, as helplessness, or as punishment for sin and immorality ${ }^{17}$; on the other hand, it is considered to accompany the positive virtues of divine spirit, divine wisdom, clairvoyance, and fair and untainted judgment. This attitude of simultaneous awe and disgust, which I refer to as the Blind Justice Paradox, is also directed towards the blindness of the Icon of Justice.

The first known interpretation of the Icon's blindness during the Middle Ages and the Renaissance was based on a European woodblock print from the year 1494 that appeared in Sebastian Brant's book Ship of Fools. ${ }^{18}$ In the print, a fool is seen covering the eyes of the Icon of Justice, who is sitting in a chair, holding a sword and scales. Scholarly interpretations of this image have viewed the woman's blindness as preventing her from properly using her sword or from seeing what is placed on the scales-that is, the blindness is a disability that prevents her from carrying out true justice. Blindness as a symbol of idiocy, incapacity, and disability

15 N S Gill, 'Lady Justice, Justice Goddess Themis, Dike, Astraia, or Roman Goddess Justitia' (About.com) <http://ancienthistory.about.com/cs/grecoromanmyth1/a/justicegoddess.htm> accessed 9 August 2016.

16 Martin Jay, 'Must Justice Be Blind? The Challenge of Images to the Law' in Costas Douzinas and Lynda Nead (eds), Law and the Image: The Authority of Art and the Aesthetics of Law (University of Chicago Press 1999) 19; David Howes and Constance Classen, Ways of Sensing: Understanding the Senses in Society (Routledge 2013) 95.

17 Georgina Kleege, Sight Unseen (Yale UP 1999) 14-15.

18 The Ship of Fools is an allegory first published in Basel, Switzerland. For additional information, see Duchan Caudill, 'Ship of Fools' (About.com) <http://archive.fo/Z9j7B > accessed 9 August 2016; Resnik and Curtis (n 12) 68. 
also appears in iconography at the Strasbourg Cathedral in France. There, the icon of the blind woman as a symbol of the Jewish synagogue, which resists the enlightenment presented by the church and continues living in sin and ignorance, is set against the icon of the Christian church, a woman who is wide-eyed and open to redemption. ${ }^{19}$

The importance attributed in ancient history to the sense of sight is also demonstrated in the 'Eye of the Mind' metaphor, developed in Greek philosophy at the time of Plato to represent the wisdom, intellect, and perception of the world that separates man from animal. The metaphor claims that a person perceives and understands the world through his or her sense of sight, which is therefore superior among the five senses and essential in order to understand the world and grow. ${ }^{20}$ This concept is also expressed in the Hebrew language, in which one word (PIKACH-פיקח) is used to describe both a person who is sighted and one who is intelligent: describing someone who can 'see with his eyes' thus simultaneously evokes the sense of 'a person with great intellect, whole in his senses and mind.'

\subsection{Blindness in Folklore and Literature and the Medical-Individual Models of Disability}

The negative cultural associations with blindness abound, and are not only transmitted through visual art. ${ }^{22}$ In folklore, blindness is often presented as punishment for inappropriate behaviour or moral misconduct connected to 'sexual offences'-self-gratification among men or promiscuous behaviour and infidelity

19 Jay (n 16) 21; Curtis and Resnik (n 11) 1756; Resnik and Curtis (n 12) 65; For an impression of the icon statues, see Mary Ann Sullivan, 'Ecclesia (Church) and Synagoga (Synagogue), Column Figures, South Transept Portal, Strasbourg Cathedral' <www.bluffton.edu/ sullivanm/ strasbourg/strasbourg.html> accessed 9 August 2016.

20 Richard Rorty, Philosophy and the Mirror of Nature (Princeton UP 1981) 38-39, 159; For a critique from the disability studies discipline of philosophical theories, which sanctify the sense of sight, see Anita Silvers, 'Formal Justice' in Anita Silvers, David T Wasserman, Marry B Mahowald and Lawerence C Becker (eds), Disability, Difference, Discrimination: Perspectives on Justice in Bioethics and Public Policy (Rowman \& Littlefield Publishers 1999) 87-89; Georgina Kleege, 'Blindness and Visual Culture: An Eyewitness Account' in Lennard J Davis (ed), The Disability Studies Reader (4th edn, Routledge 2013) 447.

21 Entry: פיקח (phonetic-Pike'ah) Eitan Avnion (ed), Sapir Dictionary: Hebrew-Hebrew Dictionary Concentrated in the Present Method (Prolog Publishing House Ltd 1997) 874.

22 I Bennett Capers, 'On Justitia, Race, Gender, and Blindness' (2006) 12 Michigan J Race \& L 203, 210 . 
among women. ${ }^{23}$ In certain cultures, blindness is considered a contagious disease, causing the banishment of blind people from society, ${ }^{24}$ and in Leviticus, blindness is among the conditions that bar a person from entering the Holy Temple. ${ }^{25}$

In folktales and Western literature from the eighteenth and nineteenth centuries, blind people are considered to be destructive and evil. ${ }^{26}$ Literature of the twentieth century continues the trope, drawing on blindness to instil fear and horror in readers. Perhaps the most prominent example is José Saramago's novel Blindness from $1995,{ }^{27}$ which describes a city plagued by 'white blindness' in which those infected with loss of sight are institutionalised. Harsh scenes describe the terror of their condition: blind people, unable to find bathrooms, are forced to urinate in the hallways of the institution; ${ }^{28}$ a blind man innocently and inadvertently comes too close to a fence and is shot by guards; horrific rapes occur within the blind community. ${ }^{29}$ From these examples alone we can see how the novel uses blindness as an analogy for depravity and loss of humanity. The fact that the story's protagonist, the doctor's wife and the only one who does not lose her eyesight, is also the one to put a stop to the abuse and deliver justice by murdering the main rapist reinforces this conclusion. ${ }^{30}$

Yaakov Steinberg's short story The Blind Woman from $1912^{31}$ tells the tale of Hannah, blind from birth and wed to a stranger, in an Eastern European Jewish community in the early twentieth century. Throughout the story, the reader must attempt to decipher Hannah's new and mysterious surroundings, her home, and her new husband's occupation. The husband, who wears heavy shoes, uses a large staff,

Annie Wagner-Lampl and George W Oliver, 'Folklore of Blindness' (1994) 88 J Visual Impairment \& Blindness 267, 269; See also Jacobus tenBroek and Floyd W Matson, 'The Disabled and the Law of Welfare' (1966) 54 California L Rev 809, 813.

24 Wagner-Lampl and Oliver (n 23) 270.

25 Leviticus 21: 18.

26 Wagner-Lampl and Oliver (n 23) 271; For an overview of scholarship discussing the negative imagery of people with disabilities in literature, see David T Mitchell and Sharon L Snyder, Narrative Prosthesis: Disability and the Dependence of Discourse (University of Michigan Press 2001) 17-21.

27 José Saramago, Blindness (1st edn, Harvest Books 1999).

28 ibid 107-08.

29 ibid 142-43.

30 ibid 152-54; For additional critical reading of Saramago's novel, see Liat Ben-Moshe, 'Infusing Disability into the Curriculum: The Case of Saramago's Blindness' (2006) 26 Disability Studies Q <www.dsq-sds.org/article/view/688/865> accessed 9 August 2016.

31 Yaakov Steinberg, The Blind Woman, The Rabbi's Daughter, Daughter of Israel, Between the Silver Bricks (Babel Publishing 2001) (Hebrew). 
and utters few words throughout the narrative, gives the reader an impression of being nearly inhuman. In contrast to the characters of Blindness, the blind woman in this story represents humanity, while the sighted person, without disability, lacks it. Steinberg thus creates a protagonist with a physical impairment and focuses the story on her doomed attempt to cope with it, conveying a sense of human helplessness against ' cruel fate' prescribed from childhood.

Blindness as reflected in folklore and literature is mirrored in the medicalindividual models of disability that frame disability as misfortune and those with disabilities as 'less equal' and incompetent. ${ }^{32}$ The medical-individual models were developed during the nineteenth and early twentieth centuries, a time when the responsibility of Western governments to provide health services for their citizens had not yet been established. Therefore, it fell on physicians to treat and advise people with regard to health-related issues. This period of time also saw the rise of institutions in an attempt to control the non-working population, comprised mainly of people with disabilities. ${ }^{33}$ Therefore, people with disabilities were excluded and segregated from society and its education system and labor market, in order to allow them to receive medical care. The exclusion of people with disabilities from society perpetuated complex processes of stigmatization and myth surrounding them and their capabilities. ${ }^{34}$ Disability was seen as something that needed to be fixed so that the disabled could fit into society, regardless of their needs, wishes, or life experiences. ${ }^{35}$ Historically in the US, disability served as an excuse for differential treatment and deprivation of rights not only with regard to disabled people, but also as a justification for the unequal treatment of the members of other groups, such as women and people of colour. ${ }^{36}$ This structuring of pathology is now referred to as 'ableism': the process by which a person's overall abilities are considered to correspond directly to his or her sensory, physical, or mental abilities

Susan Wendell, The Rejected Body: Feminist Philosophical Reflections on Disability (Routledge 1997) 27.

Mike Oliver, 'Social Policy and Disability: Some Theoretical Issues' (1986) 1 Disability, Handicap \& Society 5, 14.

34 Deborah A Stone, The Disabled State (Temple UP 1984) 107-17; Colin Barnes, 'A Brief History of Discrimination and Disabled People' in Davis (n 20) 20, 29. Anthony F LoBianco and Kathy Sheppard-Jones, 'Perceptions of Disability as Related to Medical and Social Factors' (2007) 37 J of Applied Social Psychology 1, 1-2; Susan Wendell, 'Toward a Feminist Theory of Disability' in Davis (n 20) 336, 349.

36 See generally Douglas C Bayton, 'Disability and the Justification of Inequality in American History' in Paul K Longmore and Lauri Umansky (eds), The New Disability History: American Perspective (NY UP 2001) 33-57. 
and measured against a level of productivity determined by non-disabled people. ${ }^{37}$ According to this paradigm, only those with medical-rehabilitation training are qualified to 'repair' people with disabilities, while members of the community should not be involved in choosing how best to accommodate their own physical or mental needs. ${ }^{38}$ Disability has thus been historically perceived as inherent to the person herself, hence the individual model of disability, which goes hand in hand with the medical model and views disability as a trait that an individual should try to overcome and undermines the role that myth and stigma play in the social construction of disability. ${ }^{39}$

The literary works described above greatly emphasise the difference between a disabled and a non-disabled person, and use their characters' impairments as the main catalyst for plot developments. ${ }^{40}$ Through the conscious or subconscious use of synecdoche, a literary-figurative device in which a whole is represented by its parts, the disability (blindness) essentially replaces the protagonist. Thus, Hannah from Steinberg's story is no longer a woman forced to marry a stranger and move her life to his home, but rather, a 'blind woman' whose disability forms the essence of her self. ${ }^{41}$ Disability studies scholar David Bolt describes a trend in twentieth century literature where many blind literary characters' names are displaced by The Politics of Ableism (2008) 51 Development 252, 252-53.

38 Marta Russell, Beyond Ramps: Disability at the End of the Social Contract: A Warning from an Uppity Crip (Common Courage Press 1998) 15.

39 Michael Oliver, The Politics of Disablement: A Sociological Approach (Palgrave Macmillan 1990) 11; Rod Michalko, The Difference that Disability Makes (Temple UP 2002) 6-7 and 51; Lorella Terzi, 'The Social Model of Disability: A Philosophical Critique' (2004) 21 J of Applied Philosophy 141, 142-43.

40 Disability Studies scholars David Mitchell and Sharon Snyder argue that in many Western literary pieces, disability served as an 'opportunistic metaphorical device' they call 'narrative prosthesis': 'We therefore forward reading of disability as a narrative device upon which the literary writer of "open ended" narratives depends for his or her disruptive punch. Our phrase narrative prosthesis is meant to indicate that disability has been used throughout history as a crutch upon which literary narratives lean for their representational power, disruptive potentiality, and analytical insight (...) we want to demonstrate that the disabled body represents a potent symbolic site of literary investment'. Mitchell and Snyder (n 26) 49.

41 As articulated by Rosemarie Garland-Thomson: 'A disability functions only as visual difference that signals meaning. Consequently, literary texts necessarily make disabled characters into freaks, stripped of normalizing contexts and engulfed by a signal stigmatic trait'. Rosemarie Garland-Thomson, Extraordinary Bodies: Figuring Physical Disability in American Culture and Literature (Columbia UP 1997) 11. 
labels that refer to blindness, most obviously 'the blind girl' and 'the blind man." Bolt refers to this process as 'nominal displacement, ${ }^{43}$ while demonstrating it in writings of such authors as Kenneth Jernigan, ${ }^{44}$ Mary Norton, ${ }^{45}$ and Stephen King, ${ }^{46}$ all of whom have had female blind characters who were regarded as infantile, objectified, asexual, and weak, ${ }^{47}$ similar to Steinberg's Hannah. A notable character of a blind male judge in Thomas Wolfe's 1940 novel You Can't Go Home Again, Judge Rumford Bland, is described as causing fear and panic as a result of his presence alone and as having an 'evil ghost-shadow of a smile' and a 'suggestion of a devilish humour' when he speaks. ${ }^{48}$

The perception of impairment as a barrier or tangible division between society and the disabled person links the cultural-literary perception of people with disabilities and the medical-individual models. ${ }^{49} \mathrm{I}$ argue that the connection between them is compelling because it helps to explain society's discriminatory approach towards people with disabilities-blind people in this case-throughout history, within a legal framework and otherwise.

\subsection{The Turning Point with Respect to Blindness in Culture and Law}

In the mid-1500s, about a century after the creation of the woodblock print published in Ship of Fools and the connotations given therein to blindness, the trend reversed: positive interpretations of the Icon of Justice's blindness became more prevalent. Asceticism, including an unwillingness to yield to the lust of the eyes', was increasingly promoted by various religious factions. Blind persons were considered by these ascetics to possess the superior ability to avoid visual Writing (University of Michigan Press 2013) 36-37.

43 ibid 36.

44 ibid 37.

45 ibid 39.

46 ibid 41.

47 ibid 38-39.

48 ibid $44-45$.

49 Garland-Thomson (n 41) 79; For a note discussing the low societal expectations of disabled people and the manifestation of the idea that '[d]isabled people are not just their obvious impairments', see Tom Shakespeare, Why Disabled Achievers Should Be Remembered (BBC News Blogs, 9 January 2015) <http://www.bbc.com/news/blogs-ouch-30700874> accessed 9 August 2016. 
temptations and thus, blind judges could potentially hear the parties' arguments in a neutral and objective manner. ${ }^{50}$

Later, with the onset of the early modern period and the relinquishing of the feudal law of the Middle Ages, secular groups began attributing objectivity to blindness, using this metaphor to break from the constraints of religious rule and establish the independence of the judicial branch. ${ }^{51}$ It is no wonder that in Western Europe, the image of the Icon of Justice began appearing throughout the public sphere, adorning the fronts of the public buildings of the new civil government, now disconnected from the church. Legal scholars began to distance themselves from theories of natural, divine law and embrace the verbal drafting of codes and the development of a formative-factual standard of legal norms. Interestingly, during this time of the early modern period, other types of disabilities symbolised the desire to avoid unjust judgments. An example is a 1604 fresco from the Geneva City Hall, painted by Italian artist, Cesare Giglio, depicting judges who are handless and thus cannot receive bribes. ${ }^{52}$

The Icon of Justice's blindness suited, therefore, the legal positivism movement of the period. ${ }^{53}$ Current legal theory continues to mandate that judges keep a certain distance from the cases before them and exclude any personal views and ideologies from their judgments. Justice should be 'blind', ie, objective. ${ }^{54}$ However, advocates of impartiality do admit to the difficulty of the task. The Icon of Justice's blindfold would, in reality, do little to enable impartial judging.

As part of his Theory of Justice, the philosopher John Rawls developed the 'veil of ignorance' doctrine. Rawls claimed that in order to create a fair and just process that does not lean in favour of a certain social group or conform to existing power dynamics, judges must detach themselves from their individual identities, as well as all character traits that might be relevant to the cases before them. Thus, obscuring herself behind the veil of ignorance, the decision-maker would seek to become an 'abstract human entity', able to judge equally and justly. The concept of the veil of ignorance is one of the most influential theoretical ideals of the legal system; its actual application, however, has proved to be complicated, just as the ideal of the

50 Jay (n 16) 24.

51 Curtis and Resnik (n 11) 1746.

52 ibid 1750; Sionaidh Douglas-Scott, Law After Modernity (Legal Theory Today) (Hart 2013) 216.

53 Jay (n 16) 24.

54 Thane Rosenbaum, The Myth of Moral Justice: Why Our Legal System Fails to Do What's Right (Harper Perennial 2005) 157; Scott (n 52) 217. 
Icon of Justice occupies a position that is somewhat distant from reality. ${ }^{55}$ Despite the difficulties of its implementation, however, the basic concept underlying Rawls' theory-'tactical ignorance, or 'tactical blindness ${ }^{56}$ - can be found in existing practices. Thus, for example, in law schools around the world, exams and papers are submitted to professors anonymously to be rated objectively and 'blindly."

Another scholarly camp rejects the ideal of complete objectivity out of hand, considering judgments based on one's personal perceptions as faits accomplis; they cannot be denied, and therefore the injustice should be accepted in certain cases. ${ }^{58}$ Judge and scholar Learned Hand commented a number of times on the subject, arguing that, even if most judges will never admit it, many of their decisions are not objective; a judge cannot behave like a 'clean slate' and achieve total emotional disengagement. ${ }^{59}$

A more moderate approach is offered by former Israeli Supreme Court Chief Justice and Yale Law School Professor Aharon Barak. In his book, The Judge in a Democracy, he claims that 'the judge must realize his role in a democracy impartially and objectively (...) Absence of bias is essential to the judicial process; hence the image of justice as blindfolded. ${ }^{60}$ According to Barak, the judge's objectivity is attainable, though it is not an easy task:

The objectivity required of a judge is difficult to attain. Even when we look at ourselves from the outside, we do so with our own eyes. Nonetheless, my judicial experience tells me that objectivity is possible. A judge does not operate in a vacuum. A judge is part of society, and society influences the judge. The judge is influenced by the intellectual movements and the legal thinking that prevail. A judge is always part of the people (...) He progresses with the history of the people. All of these elements contribute to the judge's objective perspective. Moreover, the judge acts within the limits of the court. He lives within a judicial tradition (...) The heavier the weight of the system, the greater the objectification of the judicial process. ${ }^{61}$

However, even Barak acknowledges that 'some subjectification of the process is inevitable (...) The personal aspect of a judge is always present, and his life 
experience neither disappears nor can disappear. ${ }^{62}$ According to Barak, it is enough for a judge to make an honest attempt to objectify his exercise of discretion, recognizing that it cannot be done in every circumstance. ${ }^{63}$

Apart from the idea of objective and just judicial decision-making, there are other virtues, such as extraordinary 'compensatory powers' or even a sixth sense, associated with blindness and blind people in Western literature. ${ }^{64}$ In ancient Greece, mystical abilities of magical healing were attributed to the blind. For instance, the blind prophet Tiresias in Sophocles's tragic play, Oedipus the King, possesses magical powers given to him by the gods as compensation for his blindness. Famous Greek poet Homer was also blind, and his poetry was considered to be 'the kind which stems from divine inspiration. ${ }^{35}$

The progressively more positive depictions of the Icon of Justice's blindness reflect an ideological trend in the Anglo-American legal system that has opened doors for blind persons to serve in influential positions. Nevertheless, structuralsocietal barriers to the full integration of blind persons in key positions in general, and in the legal profession in particular, still remain.

\section{The History of Blind Judges in Anglo-American Law}

In this section I present a number of examples of the successful integration of blind judges into the legal systems of the US and England. The integration of blind judges in the American and English systems has a 300-year history, and a number of blind judges have presided over the supreme courts in the US and England.

In the US there are currently two organisations for blind legal professionals devoted to making the profession accessible to people with visual impairments. The National Association of Blind Lawyers and the American Association of Visually Impaired Attorneys are very similar in nature and in their social goals. ${ }^{66}$ Despite the efforts of these organisations to compile information about blind legal professionals, there is no official estimate regarding the number of blind judges presiding over courts in the US. This article is the first step in filling this gap in the literature.

63 ibid.

64 Bolt (n 42) 69-76.

65 Wagner-Lampl and Oliver (n 23) 272-74.

66 Associated with the umbrella organisation, the American Council of the Blind (ACB). 
Disability studies scholars called attention to the phenomenon of 'false admiration' of people with disabilities by non-disabled members of society and mainstream media. ${ }^{67}$ The idea is that disabled individuals and professionals are being praised and put on a pedestal for routine tasks that they perform as part of their jobs, just because they live with disabilities. ${ }^{68}$ The patronising message behind the phenomenon of 'false admiration' is that people with disabilities are less capable or should have things done for them, and therefore should be praised when they do it themselves. ${ }^{69}$ In this section, I make an effort to avoid this patronising view and present the experiences and stories of blind judges that include hardships and failures alongside success and appreciation (as opposed to false admiration), as these are part of every professional career.

\subsection{Stories from England}

London of the mid-eighteenth century was a dangerous city. Between the years 1748 and 1754 the city experienced a wave of violence and crime that continued unabated despite the tough stance taken by the legal system and legislators against even petty crimes. In those years, Sir John Fielding served as a magistrate at the Westminster Court. ${ }^{70}$ In 1754, Fielding, who had gone blind about a decade beforehand, took upon himself the implementation of a programme to eliminate crime in the city. The programme had been devised by his half-brother, renowned judge and author

Ben Whitburn, 'Attending to the Potholes of Disability Scholarship' in Tim Corcoran, Julie White and Ben Whitburn (eds), Disability Studies: Educating for Inclusion (Sense Publishers 2015) 215, 221; Katie Ellis and Gerard Goggin, Disability and the Media (Palgrave Macmillan 2015) 62-63; Emily Rapp Black, 'My Paralympic Blues' The New York Times (New York, 31 August 2016) <http://www.nytimes.com/2016/08/31/opinion/my-paralympic-blues.html> accessed September 19, 2016.

Late Australian comedian and advocate Stella Young used the term 'inspiration porn' to describe the objectification of disability, both in media and in everyday interactions. See Stella Young, Inspiration Porn and the Objectification of Disability (2014) <https://www.youtube. com/watch?v=SxrS7-I_sMQ > accessed 16 October 2016; Ellis and Gerard Goggin (n 67) 63. Richard M Keller and Corinne E Galgay, 'Microaggressive Experiences of People with Disabilities' in Derald Wing Sue (ed), Microaggressions and Marginality: Manifestation, Dynamics and Impact (Wiley 2010) 241, 255-56.

70 J M Beattie, 'Sir John Fielding and Public Justice: The Bow Street Magistrates' Court 17541780’ (2007) 25 LHR 61, 61. 
Henry Fielding, who had recently passed away. ${ }^{71}$ Fielding implemented the plan so successfully that within two years he was able to curb the criminal activity of the city's powerful gangs. His success earned him accolades as the 'most creative judge of the eighteenth century. He was eventually knighted. ${ }^{72}$ As a tribute to his brother, Fielding turned the latter's house on Bow Street into the headquarters from which he headed his operations for twenty-six years, until his death in $1780 .^{73}$

One of Fielding's greatest successes was his establishment of an innovative bureaucratic mechanism for investigating crime, which was based on collecting information and cataloguing it in archives. Fielding even utilised the main promotional medium of those days - the daily press - to publish reports of crimes, descriptions of suspects and awards for those assisting the investigation. ${ }^{74}$ Fielding created novel practices pertaining to the management of the criminal process, making it accessible to the public, and thus set into motion a mechanism later named 'public justice. ${ }^{75}$ The name reflected his commitment to serving the most marginalised members of English society. He also arranged workshops and classes at designated institutions for abandoned children and youth with a propensity towards crime. Fielding is quoted arguing that, although his blindness-which was caused by an accident-was perceived by everyone around him as a disaster, he himself did not see it that way at all. ${ }^{76}$ Interestingly, however, Fielding did not provide any official support for people with visual impairments.

Despite his success story, about 200 years after Fielding's death, in 1946 an order was issued in England that prohibited blind judges from receiving the status of magistrate. The argument underlying the order was that the disability of these judges prevented them from forming a proper impression of the defendants appearing before them. ${ }^{77}$ In 2001, the order was revoked by then British Minister

71 John Dashney, 'The Blind Beak of Bow Street' <https://nfb.org/images/nfb/publications/ books/kernel1/kern0808.htm> accessed 9 August 2016.

72 Beattie (n 70) 63.

73 Dashney (n 71).

74 Beattie (n 70) 69.

75 ibid 70.

76 Dashney (n 71). This remark, as well as Fielding's success in creating a revolution in the execution of the criminal process, testifies to the deep roots of the social model of disability among disabled people, even before it was officially articulated in the 1970s, as will be discussed later in the article.

77 Tom Utley, 'Blindness a Virtue in Justice but Seldom on the Bench' The Telegraph (London, 27 June 2001) <http://www.telegraph.co.uk/comment/4263377/Blindness-a-virtue-in-Justicebut-seldom-on-the-Bench.html> accessed 9 August 2016. 
of Justice Lord Derry Irvine, who appointed nine blind judges after having them serve for a trial period. ${ }^{78}$

In 1990 the first blind judge, Sir John Wall, was appointed to England's High Court of Justice, the highest civil court in England. ${ }^{79}$ Wall, who went blind when he was eight years old, is described as a man blessed with a phenomenal memory. He began his career as an attorney in the private sector, after studying throughout his life at both institutes for blind people and integrated institutes. Wall explained that finding employment after his graduation from Oxford had been a difficult task, and that he had therefore decided to focus his efforts on advocating for the employment of people with disabilities. ${ }^{80}$ Unlike John Fielding, Wall worked extensively to promote the interests of people with disabilities, and he was even knighted in 2000 for his societal contributions and services. ${ }^{81}$ Wall retired from the English court in 2002 but continued his social activity from outside the court until he passed away in $2008 .{ }^{82}$

In 1997, legal scholar Amir A. Majid was appointed as a part-time immigration judge. ${ }^{83}$ Majid, who went blind later in life while a student at a university in Pakistan, where he was born, is a prominent scholar in international law and also works on disability-related issues.

Judge John Lafferty, who has been blind from birth, was appointed to be a judge in Snaresbrook Crown Court, England's largest court, in 2007 and currently serves on the bench. ${ }^{84}$ Like Wall, Lafferty, who practised law as a solicitor for 20 years

Matt Born, 'Lord Chancellor Lifts Ban on Blind Magistrates' The Telegraph (London, 26 June 2001) $<$ http://www.telegraph.co.uk/news/uknews/1310223/Lord-Chancellor-lifts-ban-on-blindmagistrates.html> accessed 9 August 2016; 'Bill Set to Become First Blind Magistrate' The Bolton News (Bolton, 13 July 2001) <http://www.theboltonnews.co.uk/news/6019826.Bill_set_ to_become_first_blind_magistrate/> accessed 9 August 2016.

79 This is one house out of three constituting the Supreme Court in England.

80 John Wall, 'The Rights of Blind People' (2003) 16 Community Eye Health J <http://www.ncbi. nlm.nih.gov/pmc/articles/PMC1705870/> accessed 9 August 2016.

81 'Birthday Honours List-United Kingdom' The London Gazette (Supplement No 1, London, 16 June 2000) <https://www.thegazette.co.uk/London/issue/55879/supplement/1/data.pdf> accessed 9 August 2016.

82 'Sir John Wall: First Blind High Court Judge of Modern Times' The Times (London, 11 December 2008) <http://www.thetimes.co.uk/tto/opinion/obituaries/article2083884.ece> accessed 29 August 2016.

83 'Blind Lecturer a Judge' Times Higher Education (London, 21 November 1997) <https://www. timeshighereducation.com/news/blind-lecturer-a-judge/104451.article > accessed 9 August 2016.

84 Jonathan Rayner, 'Interview: John Lafferty' The Law Society Gazette (28 September 2015) $<$ http://www.lawgazette.co.uk/people/interview-john-lafferty/5051158.fullarticle> accessed 9 August 2016. 
after graduating from the University of Leeds, admitted that finding employment after graduation had been a difficult task. In Lafferty's words:

Many prospective employers are unable to make the leap of imagination to see how a blind person can do a job that is regarded as difficult, such as practicing as a lawyer (...) If you can just have a dialogue with a prospective employer, your blindness (...) will be disregarded and their anxiety eased. That's what I hope my history will help achieve; telling employers that everything is possible. Hard work and determination will allow you to overcome all obstacles. ${ }^{85}$

\subsection{Stories from the United States}

One of the earliest appointments in the US was in 1972, when a blind judge was chosen to sit on the Fourth Circuit in Duval County, Florida. Judge Louis Corbin was appointed to the court at the early age of 35 , after eight years as an attorney in the private sector. Corbin, who had gone blind at the age of six as a result of an accident, spoke many times about the advantages of being a blind judge, able to avoid being distracted by appearances or attempts to influence and impress him. ${ }^{86}$ Throughout the years in which he sat on the bench, Corbin refused to recuse himself from cases and transfer them to other judges due to his disability, ${ }^{87}$ including cases that included evidence in the form of video footage; during these cases, Corbin would instruct the lawyers to describe the content of the footage to him in detail. In 1984, a torts case about a man killed in a work accident came before Corbin. The plaintiff-the wife of the deceased-requested that Corbin recuse himself, arguing that, as a blind judge, he could not form an impression from the photos of her late husband's injuries. Corbin refused, subsequently claiming that during his career he had successfully tried dozens of cases that included visual evidence. ${ }^{88}$

85

86 'Judge ibid.

ibid.

'Judge Blind, Not Justice' Cape Girardeau Southeast Missourian (1 September 1974).

'Blind Judge Refuses to Disqualify Himself' Ocala Star-Banner (Jacksonville, 14 August 1984) <http://news.google.com/newspapers?nid=1356\&dat=19840814\&id=1CEVAAAAIBA J\&sjid=bgYEAAAAIBAJ\&pg=6899,7819745 > accessed 9 August 2016; In 1987, Corbin’s career came to an abrupt end, after he resigned as part of his punishment for attempted sexual battery against a 17-year-old girl. See 'Blind Judge Reports to Prison' Associated Press (Jacksonville, 7 October 1987) <http://www.apnewsarchive.com/1987/Blind-Judge-Reports-To-Prison/id9892b5de46f8066e5d584b62b53a7b58> accessed 15 December 2016. 
Associate Circuit Judge Nicholas T. Pomaro of Cook County in Illinois was appointed to the bench in $1976 .{ }^{89}$ He served on the bench for thirty-four years 'earning a reputation for being an exceptionally fair, diligent, intelligent, and sensitive jurist. ${ }^{90}$ At one time, while adjudicating a murder trial, a lawyer challenged Pomero's ability to review a videotaped confession given to the police and asked Pomero to recuse himself 'because he would not be able to see the defendant's expression'. Pomero refused and was upheld by the state Supreme Court. ${ }^{91}$ Pomero said that, although he could not see the witness before him, he developed 'kind of a sixth sense' that allowed him to 'form these images in my brain, but those images are not perceived through sight, but through imagination, sounds, smell, feel and the other senses. ${ }^{92}$

Judge Tony Cothren, who gradually went blind as a child, was appointed to the Tenth Circuit in Jefferson County, Alabama, in 1996. He, like Pomero and Corbin, claims that his blindness does not interfere with his work as a judge. Cothren has stated that when he hears the voice of a man or a woman, he envisions in his mind an abstract shape of the person. He has also argued that he can envision his computer even though he cannot commit the vision to memory. ${ }^{93}$ Cothren's career has been an eventful one. In 1998, he was suspended after being accused of inappropriate behaviour and failure to meet deadlines. Claims made against him argued that he tended to fall asleep on the bench. Cothren denied these allegations. The affair was of great interest to the blind community in the US, some of whom argued that these were false accusations arising from discriminatory attitudes toward Cothren as a person with a disability, and that Cothren had been suspended simply because he was the only blind judge in Alabama. Others, however, questioned the propriety of Cothren's claims that, as a disabled person, he was more dependent on his legal assistants, and that these assistants were responsible, through their own negligence,

Jim O’Donnel, 'Judge on His Own Merits' Chicago Tribune (Chicago, 8 September 1996) <http://articles.chicagotribune.com/1996-09-08/features/9609080091_1_senior-judgescriminal-felony-blind > accessed 9 August 2016.

90 Hal Dworkin, 'Testing for Total Inaccessibility in Examination Under the ADA: A Case Study of Logic Games’ (2014) U Ill L Rev 1963, 1964-65.

91 'JudgewhoIsBlindRelieson “What's Inside" forTruth' TheNew YorkTimes(New York,24June 1984) <http://www.nytimes.com/1984/06/24/us/judge-who-is-blind-relying-on-what-s-insidefor-truth.html> accessed 9 August 2016. ibid.

93 Rick Bragg, 'A Sixth Sense and Sensibility' The New York Times (New York, 22 October 1996) <http://www.nytimes.com/1996/10/22/us/a-sixth-sense-and-sensibility.html> accessed 9 August 2016. 
for the irregularities in his chamber. ${ }^{94}$ Regardless of culpability, it is clear that Cothren faced increased public scrutiny for his disability in a time of crisis.

Judge Peter J. O'Donoghue, who gradually lost his eyesight beginning at the age of 12, was appointed to the Civil Court of the City of New York in 1996, and in 2002 was promoted to the New York State Supreme Court in Queens County. O'Donoghue is considered an excellent judge with careful attention to detail, a superb memory, and a strong code of professional ethics. ${ }^{95}$

Judge Richard B. Teitelman was appointed to sit on the Supreme Court of Missouri from 2002 until 2016 (after serving as judge at a lower court since 1998). ${ }^{96}$ Teitelman also went blind gradually as a child, an effect of which, he believes, is his extraordinary memory. He views his disability as an advantage, bringing a unique and interesting perspective to the judge's table. He is known as an advocate for disability rights, and has received a Lifetime Achievement Award for his work. ${ }^{97}$

As of today, two blind judges have presided over the US Federal Courts. In 1994 Judge David Tatel was appointed to the US Court of Appeals for the District of Columbia Circuit. He still holds the position and is regarded as an excellent judge: 'because he can't see people, he sees through them. He picks up nuances that those of us who are sighted cannot. ${ }^{98}$ Judge Richard C. Casey was appointed to the Federal Court for the Southern District of New York in 1997.

Unlike other blind judges who went blind at a young age, both Tatel and Casey became blind later in life. Tatel went blind after law school and became a

Marc Maurer, 'The Search for Anonymity' An Address (9 July 1998) <https://nfb.org/images/ $\mathrm{nfb} /$ publications/convent/banque98.htm> accessed 9 August 2016.

95 Charlie LeDuff, 'This Justice Is Blind, but He's a Great Listener' The New York Times (New York, 7 September 1997) <http://www.nytimes.com/1997/09/07/nyregion/this-justice-isblind-but-he-s-a-great-listener.html> accessed 9 November 2016; See also the information page regarding Judge O'Donoghue at the Civil Court of the City of New York website: 'Hon Peter J O’Donoghue' (NY States Unified Court System) <https://iapps.courts.state.ny.us/ judicialdirectory/Bio?JUDGE_ID=phuHnjfzplhkA0bEto0z0g\%3D\%3D> accessed 9 August 2016.

96 The information page regarding Judge Teitelman at the Missouri Supreme Court website: 'Judge Richard B Teitelman' (Missouri Courts) <www.courts.mo.gov/page.jsp?id=197> accessed 9 August 2016.

97 Jason Kander, Official Manual State of Missouri 2013-2014 (Supreme Court of Missouri 2013) $234<$ http://s1.sos.mo.gov/cmsimages/bluebook/2013-2014/5_Jud.pdf\#judbranch> accessed 9 August 2016.

98 Barbara Slavin, 'A Judge of Character: Although He's Blind, David Tatel Skis, Runs and Climbs Mountains. By Summer's End, He May Be a Top Jurist Too' Los Angeles Times (Los Angeles, 28 July 1994) <http://articles.latimes.com/1994-07-28/news/ls-21024_1_david-tatel/2> accessed 9 August 2016. 
senior partner at an influential Washington law firm. ${ }^{99}$ Casey only became fully blind in his fifties, as a result of an illness that he contracted while working as an attorney for a private law firm in Manhattan. ${ }^{100}$ At a lecture he gave in 1998 at a convention for the National Federation of the Blind, he introduced himself as a newcomer to the blind world and called for a change in societal attitudes toward blind people, as well as people with disabilities in general, and for their integration in all fields of life. ${ }^{101}$

At the time of Casey's appointment to the Federal Court, many raised concerns and doubts regarding his ability to function properly as a judge. In the end, these fears were proven to be unfounded and Casey presided for almost a decade, deliberating on matters of great interest to the American public, such as reproductive rights. Casey passed away in March 2007 at the age of $74^{102}$

\subsection{Existing Barriers and the Social Model of Disability}

The election of congenitally blind Richard Bernstein to the Michigan Supreme Court in December 2014 is significant since all of the American judges with visual impairments appointed prior to his election went blind at some point in their lives. Being born blind, however, figures centrally for Bernstein himself:

I genuinely believe as a blind person, I was created this way for a reason (...) It's not easy. It's incredibly challenging, incredibly difficult. But at the same time, it makes your life incredibly fulfilling. If I hadn't been born blind, I would not have lived my life with the same sense of mission and focus and purpose. ${ }^{103}$

Currently there are still structural barriers that prevent congenitally blind people and those who went blind at an early age from entering the legal profession.

99 ibid.

100 Larry Neumeister, 'Blind Federal Judge an Inspiration' Associated Press (New York, 28 October 2001), <www.jwen.com/rp/articles/blindjudge.html> accessed 9 August 2016.

101 Richard C Casey, A Jurist Who Happens to Be Blind in Federal Courts <www.nfb.org/Images/ $\mathrm{nfb} /$ Publications/bm/bm98/bm981202.htm $>$ accessed 9 August 2016.

102 'Richard Conway Casey, 74, Blind Federal Judge, Dies' The New York Times (New York, 24 March 2007) <www.nytimes.com/2007/03/24/obituaries/24casey.html?_r=1> accessed 9 August 2016.

103 Louise Knott Ahern, 'Michigan's 1st Blind Justice Aims to Inspire' Detroit Free Press (Detroit, 11 January 2015) <http:/www.freep.com/story/news/local/michigan/2015/01/11/michigans1st-blind-justice-richard-bernstein-aims-inspire-others/21611021/> accessed 9 August 2016. 
Recognition of these structural barriers is consistent with ideas that ground the social model of disability about societal disabling factors.

Since the mid-1970s, a new movement has challenged the medical and individualistic accounts of disability that were previously presented. ${ }^{104}$ The underlying paradigm of the disability rights movement is the social model of disability. This model emerged in England in the early 1970s with the Union of Physically Impaired Against Segregation (UPIAS), a group comprised of physically disabled veterans who advocated for the deinstitutionalisation of people with disabilities, and who clearly articulated the idea that society plays a significant role in the disablement of people with disabilities. ${ }^{105}$ This idea has since gained broader recognition. ${ }^{106}$ The social model argues that people with disabilities are perceived as an inferior group due to the social construction of reality and environments, and thus challenges the medical-individual models, which imagine impairment as the sole reason for discrimination and differential treatment. The assumption underlying the social model is that disability is not an inherent phenomenon stemming from the individual, but rather, a phenomenon dependent on wider social contexts that stems from the ways in which environments and systems are constructed as well as the ways in which societal impressions regarding people with disabilities are constructed. ${ }^{107}$ Over the years, the social model was criticized for not encompassing the full experience of disability, which often includes pain and hardship related to the body and impairments, ${ }^{108}$ and for undermining the need for health care as well as the role of doctors, social workers and other professionals in the treatment of disability. ${ }^{109}$ In response, over the years, the social model was further developed by scholars and policy makers and its ideas were implemented into law and public policy. A contemporary view of disability that stems from the original social model views it as complex and fluid, rather than a dichotomous process of presence or absence, which is multidimensional, dynamic, bio-psycho-

104 Joseph P Shapiro, No Pity: People with Disabilities Forging a New Civil Rights Movement (Broadway Books 1995) 49-58.

105 Tom Shakespeare, Disability Rights and Wrongs: Revisited (2nd edn, Routledge 2014) 12-17.

106 Katharina C Hayer, Rights Enabled: The Disability Revolution, from the US, to Germany and Japan, to the United Nations (University of Michigan Press 2015) 23.

107 Oliver (n 39) 11.

108 Tom Shakespeare and Nicholas Watson, 'The Social Model of Disability: An Outdated Ideology?' (2002) 9 Research in Social Science and Disability 2, 20.

109 Tom Shakespeare, 'Still a Health Issue' (2012) 5 Disability \& Health J 129, 129-30. 
social and interactive in nature, ${ }^{110}$ that is formulated through a complex interaction between the impairment and the social environment. ${ }^{111}$ This view is also reflected in the United Nations' Convention on the Rights of Persons with Disabilities:

Recognizing that disability is an evolving concept and it results from the interaction between persons with impairments and attitudinal and environmental barriers that hinders their full and effective participation in society on an equal basis with others. ${ }^{12}$

An alternative paradigm, the social model has served as the basis for domestic legislation around disability discrimination throughout the Western world. A wellknown example of such legislation that exists in the US, England and Israel is the requirement that employers provide reasonable accommodations (or adjustments) for qualified employees or job applicants with disabilities, and adjust the work environment to meet their needs (rather than expecting the person to adapt to the work environment). ${ }^{113}$

For hundreds of years, across societies and cultures, people with disabilities were (and to some extent still are) considered 'unemployable. ${ }^{, 14}$ In 1963 in England, for example, only about $6 \%$ of those registered as blind were employed, and about $63 \%$ of those who worked were engaged in sheltered or home employment. ${ }^{115}$ Almost 50 years later, in 2012, only 34\% of the registered blind population in England were employed. ${ }^{116}$ In the US, according to data originating from the Bureau of Labor Statistics from March 2014, only 37.7\% of the blind population are

110 Irving Kenneth Zola, 'Disability Statistics, What We Count and What It Tells Us-A Personal and Political Analysis' (1993) 4 J Disability Policy Studies 9, 18.

111 Saad Z Nagi, 'Disability Concepts Revisited: Implications for Prevention' in Andrew M Pope and Alvin R Tarlov (eds), Disability in America: Toward a National Agenda for Prevention (National Academies Press 1991) 309, 326; Carmelo Masala and Donatella Rita Petretto, 'From Disablement to Enablement: Conceptual Models of Disability in the 20th Century' (2008) 30 Disability \& Rehabilitation 1233, 1234.

112 Convention on the Rights of Persons with Disabilities (adopted 13 December 2006, entered into force 3 May 2008) 2515 UNTS 3, preamble (section e).

113 In the US: Americans with Disabilities Act 1990, sections 12111-12112, 104 Stat 328 (ADA); in England: Equality Act 2010, sections 55(6), 60; in Israel, Equal Rights for Persons with Disabilities Law 1998, section 8 (Israeli Equal Rights Law). tenBroek and Matson (n 23) 810; Stone (n 34) 55.

115 tenBroek and Matson (n 23) 810.

116 Fred Reid, 'Blind Rights Activist: "In the UK, 66\% of visually impaired are unemployed"' (EurActive.com) 23 October $2012<$ http://www.euractiv.com/specialreport-eye-active-ageing/ blind-rights-reporter-paints-var-interview-515575> accessed 9 August 2016. 
'in the labor force. ${ }^{117}$ In a conversation I had in August 2016 with Justice Bernstein, the most recently elected blind judge in the US, he attributed part of his success to his affluent background. Without the support of his family and their means, he believes that he would probably have been among the majority of blind Americans who are unemployed.

Stigma has been found to be a key barrier in gaining employment and social inclusion for blind people. ${ }^{118}$ Bernstein believes a committee would never have appointed him to the bench because of latent stigmas and disbelief in his abilities. He attributes his appointment to the fact that, in the US, state high court judges are elected by the public, and he believes that he had the opportunity to affect the voters and convince them of his abilities through the campaign he ran under the slogan 'Blind Justice'. According to Bernstein, the people of Michigan wanted to elect a justice with whom they felt a connection, who can connect with their hardships and struggles and who cares about their issues. Although Michigan is known as a swing state, Bernstein became one of only two endorsed justices who was nominated by the Democratic Party, out of seven in the Michigan Supreme Court.

It is not only stigma, however, that gets in the way of blind people who aspire to go on the job market, particularly the legal market. Despite the fact that the Americans with Disabilities Act (ADA) (as well as other disability antidiscrimination laws around the world) prohibits discrimination in higher education and requires accommodations, including assistive technologies, to be applied to ensure accessibility, ${ }^{119}$ the main threshold to American law schools, the Law School Admission Test (LSAT), is completely inaccessible. ${ }^{120}$ This is due to 'logical games' exercises that require the drawing of diagrams in order to solve them. ${ }^{121}$ Bernstein himself was admitted to Northwestern University Law School after convincing the school to accept him based on his academic record, extracurricular activities and

117 'Interpreting Bureau of Labor Statistics Employment Data' (AFB American Foundation for the Blind, 2015) <http://www.afb.org/section.aspx?SectionID=15\&SubTopicID=177> accessed 9 August 2016.

118 Bonnie O’Day, 'Employment Barriers for People with Visual Impairments' (1999) 93 J of Visual Impairment and Blindness 627, 630; Cecilia Benoit, Mikael Jansson, Martha Jansenberger and Rachel Phillips, 'Disability Stigmatization as a Barrier to Employment Equity for Legally-Blind Canadians' (2013) 28 Disability \& Society 970, 976-81.

119 ADA (n 113) sections 12181(7)(J), 12189; Equality Act (n 113) part 2 chapter 6; Israeli Equal Rights Law (n 113) part 7 chapter 1.

120 See generally Dworkin (n 90).

121 ibid 1966-67, 1974-76. 
letters of recommendation alone. ${ }^{122}$ Nevertheless, this can no longer be the case for other blind Americans who wish to go to law school, since prospective law students are now required by the Law Students Admission Council (LSAC) to take the test. ${ }^{123}$ In June 2016, litigation brought against the American Bar Association, which only accredits US law schools that admit students according to the LSAT, was dismissed while the Sixth Circuit Court decided that the lawsuit should be filed against LSAC, the body that actually administers the exam. ${ }^{124}$ Such a suit is likely to be filed soon by Angelo Binno, who was rejected from a few law schools due to his LSAT results and who started the legal battle against the LSAC in $2011^{125}$

As the stories presented here indicate, blind judges have been successfully incorporated into judicial systems, despite ambivalent attitudes towards and barriers against disability and blindness both societal and legal. As we shall see in the next section, the Israeli judicial system has also grappled with discomfort and bias when it comes to having blind persons serving in judicial roles.

\section{Potential for Integrating Blind Judges into the Israeli Judiciary}

The case of Amidar v Hai was argued in the Tel Aviv District Court in 2005 and concerned the request of Amidar, an Israeli state-owned housing company, to disqualify an arbitrator from her duties on account of her blindness. The case involved two parties that had signed an arbitration agreement, according to which attorney Heruta Harel would serve as arbitrator in any dispute between them. The dispute that emerged between the parties involved an agreement to convert an industrial building into a residence for new Eastern European immigrants. The plan to convert the building was not approved by the Local Planning and Zoning Committee, and Amidar cancelled the project. The arbitrator was finishing her review of the materials presented by the parties as well as of the various schemes related to the dispute when she lost her vision due to an illness. She therefore

122 Corey Wheeler, 'Farewell, Bernstein' The South End (Detroit, 7 December 2010) <http:// www.thesouthend.wayne.edu/news/article_91e85791-165d-511b-9a68-5a015e04c8c8.html> accessed 9 August 2016.

123 Dworkin (n 90) 1966.

124 Melissa Daniels, '6th Circ. Tell Blind Man ABA Is Wrong Target for LSAT Suit' Law360 (New York, 16 June 2016) <http://www.law360.com/articles/807873/6th-circ-tells-blind-man-abais-wrong-target-for-lsat-suit> accessed 9 August 2016. ibid; Dworkin (n 90) 1965-66. 
requested that the parties allow her to hire a paid assistant at their expense so that she could complete the work remaining and deliver a decision. ${ }^{126}$ In light of these circumstances, Amidar petitioned the Tel Aviv District Court with a request to dismiss the arbitrator based on section 11(3) of the Arbitration Law allowing for the removal of an arbitrator in the event that she is unable to fulfil her duties. ${ }^{127}$ According to Amidar, the arbitrator's blindness constituted a disability preventing her from fulfilling her duties for two reasons: first, the arbitrator would no longer be able to weigh evidence or review the schemes, plans, and other materials; and second, hiring a legal assistant would taint her opinion with an external perspective. ${ }^{128}$ Despite legal aspirations of judges' 'metaphorical blindness', in this case the arbitrator's blindness was seen by Amidar as working against her, manifesting what I have here termed the Blind Justice Paradox: she had been struck by a disability that rendered her helpless. This case, therefore, demonstrates the paradoxical treatment of blindness in the legal realm: first as a physical attribute that implies incapability and second as a metaphor for just treatment under the law.

In her decision, Judge Rina Meshel determined that disqualifying an arbitrator from her duties was an extreme measure that would not only tarnish the arbitrator's reputation, but would also damage the quasi-judicial institution of arbitration. Therefore, only exceptional circumstances could justify such an action. Such exceptional circumstances could be, for example, a severely incapacitating disease that could cause 'real likelihood, under the circumstances, that the arbitrator will not produce a true and just arbitration award. ${ }^{129}$ The judge reviewed a number of Israeli evidentiary legal tests and determined that a blind judge could use them appropriately and just as well as any other judge. ${ }^{130}$

126 DC Amidar (n 3) paras 1-4 (Meshel J).

127 ibid para 6. Similar clauses to this section in other countries are, for example, rule 18 to the Commercial American Arbitration Association Rules, which allows for the disqualification of an arbitrator due to 'inability or refusal to perform his or her duties with diligence and in good faith'; art 10.1 to the London Court of International Arbitration (LCIA) Rules which provides that ' $[\mathrm{i}] \mathrm{f}$ (...) any arbitrator dies, falls seriously ill, refuses, or becomes unable or unfit to act, either upon challenge by a party or at the request of the remaining arbitrators, the LCIA Court may revoke that arbitrator's appointment and appoint another arbitrator'; Section 5 of the Federal Arbitration Act 2001; For further comparative analysis, see Christopher Koch, 'Standards and Procedures for Disqualifying Arbitrators' (2003) 20 J Int'l Arb 325.

128 DC Amidar (n 3) para 6.

129 ibid paras 6-7.

130 ibid paras 8-10. 
Judge Meshel further discussed the potential for blind or visually impaired jurists to serve as judges, although no blind judges have ever been appointed in Israel to date. She referred to sections 2-3 of the Israeli Equal Rights for Persons with Disabilities Law (Equal Rights Law), the Israeli counterpart to the ADA, which established the right of a disabled person to equally participate in all areas of life (...) while fully maximizing his potential'. In addition, the judge gave an example from comparative law, referencing the case of the late US Federal Court judge Richard C. Casey. ${ }^{131}$ She concluded by determining that loss of eyesight could not justify relieving an arbitrator of her duties, and completely rejected Amidar's arguments.

Consistent with alternative views on disability and the social model, Judge Meshel's decision set a high bar, supporting a view of disability as constructed, for the most part, through complicated processes of stigmatisation by society at large. ${ }^{132}$ In contrast, the arguments of the plaintiff, Amidar, essentialised the difference presumably found in the arbitrator due to her disability. They even suggested that the arbitrator's blindness impaired her cognitive ability and discretion, both by implying that it would diminish her analytical ability and thus prevent her from evaluating the importance of evidence, and by claiming that the arbitrator would be more easily influenced by the opinions of her legal assistant.

These claims mirror more common conflation by Israeli society (among others) of sensory with cognitive disabilities. According to this conflation, a person with a sensory or a physical disability is often perceived as also having a cognitive or mental impairment as well, and incapable of dealing with complicated tasks that require analytical resources. The judgment in Amidar v Hai, by contrast, emphasises blind individuals' capabilities over their limitations, promoting the view that a blind person is able to fill positions other than those traditionally designated for this population. These traditional occupations include operating call centres and working in assembly lines in sheltered workshops; ${ }^{133}$ they are often mundane, and do not require imagination or talent. ${ }^{134}$ According to the judgment, a blind person is fully capable of filling an honourable judicial position of high social standing, requiring analytical and deductive skills, wisdom, and vast knowledge. I believe

131 ibid para 15.

132 ibid.

133 Shlomo Deshen, Blind People: The Private and Public Life of Sightless Israelis (State University of New York Press 1992) 63.

134 ibid 65; Dean W Tuttle and Naomi R Tuttle, Self-Esteem and Adjusting With Blindness: The Process of Responding to Life's Demands (3rd edn, Charles C Thomas Publisher 2004) 32. 
that this ruling is highly courageous; it is one of the first stepping-stones towards allowing people with disabilities to achieve legal recognition of their rights and equal integration into society.

Regardless of the importance and sophisticated nature of this decision, however, in paragraph 15 of the judgment we find an excerpt reflecting the views of the medical-individual models of disability:

And indeed, the legal sphere, and the judiciary in particular, should be at the forefront of the fight for the rights of society's weakest links. ${ }^{135}$

This phrase encapsulates an attitude of charity and pity towards people with disabilities, and the perception of disability as a tragedy or divine punishment. ${ }^{136}$ This mode of thinking stands in contrast to more progressive perceptions aligned with the social model which, as mentioned, views disability as a derivative of society's perception, and not a phenomenon immanent to the individual. Although there are those who claim that the 'mercy approach' produced advancement in legislation and recognition of the rights of people with disabilities, many activist groups have tried to detach themselves from this approach and from assumptions of 'inherent difference' and 'inferiority' connected to disability. ${ }^{137}$

These contradictory approaches are exemplified in the ideological rivalry in the 1980s between two Israeli organisations for the blind. While the Centre for the Blind advocated for 'community rehabilitation' activities, the Association of Blind University Graduates (ABUG), a small circle of about one hundred blind members who wished to integrate into society as professionals, believed that blind people should only demand benefits materially relating to lack of vision, objecting to the view of blindness as a tragedy in order to promote the integration of blind people into larger society. ${ }^{138}$ This debate was ignited in the wake of a religious institute having published a fundraising flyer in which its blind students were portrayed as its wards, and their condition as a 'cruel fate. While the Centre for the Blind refused to publicly comment on the flyer, the members of ABUG harshly criticised it, as well as the Centre's behaviour. ${ }^{139}$ Even today, in the post-disability rights legislation era, scholars argue that disability is still not widely perceived as a human rights

137 ibid 23-24; One such group is UPIAS, which first articulated the social model in the 1970s: see Shakespeare (n 105) 12-17.

138 Deshen (n 133) 155-56.

139 ibid 162-63. 
issue and that mercy and good will underlie the treatment of disability. ${ }^{140}$ As I will point out below, this kind of a 'mercy-based' (as opposed to 'rights-based') approach, which found its way even into Judge Meshel's advanced decision in the short excerpt above, would become central in a later decision on this case.

The Tel Aviv District Court was faced with the Amidar case a second time after the delivery of the arbitration award in the Hai $v$ Amidar judgment. ${ }^{141}$ This time Judge Uri Goren considered Amidar's application to dismiss the arbitration award. Among Amidar's arguments, which included alleged procedural flaws and irregularities in the previous trial, Amidar also repeated its claims regarding the blind arbitrator's inability to form an opinion from the witnesses and documents presented to her. This time, Amidar invoked the Hebrew Law, which, it argued, did not allow a blind judge to preside. Although primary sources of Hebrew Law such as the Mishnah and Shulhan Aruch prohibit the appointment of a blind judge, even while admitting a judge who is blind in only one eye, a few later rabbis and Jewish scholars have ruled for allowing blind persons to serve in judicial rules. ${ }^{142}$ Judge Goren therefore denied Amidar's application to dismiss the arbitration award and instructed it to be confirmed, while siding with the legal ruling of Judge Meshel.

This was not, however, the end of the story. Amidar filed for permission to appeal Judge Goren's decision to the Supreme Court, and the case was brought before a panel of three justices. ${ }^{143}$ In an exceptional move, the Supreme Court revoked the second part of the arbitration award, reasoning that it contradicted a former non-appealable court's judgment and therefore defied ordre public. Indeed, upon accepting the judgments of Judge Goren and Judge Meshel, Justice Yoram Danziger dismissed Amidar's claims regarding the arbitrator's disability. However, he avoided making any fundamental statement regarding the ability of blind people to take part in the judiciary as Judge Meshel had done. In paragraph 20 of his judgment, Justice Danziger wrote:

140 Mary Johnson, Make Them Go Away: Clint Eastwood, Christopher Reeve and the Case Against Disability Rights (Advocado Press 2003) 57, 66; Michael Waterstone, 'The Cost of Easy Victory' (2016) 57 Wm \& Mary L Rev 587, 614.

141 DC (TA) 191/06 Hai v Amidar Co for Immigrant Housing Ltd (31 October 2007) Nevo Legal Database (by subscription) (Isr).

142 Richard Gottheil and Judah David Eisenstein, 'The Blind in Law and Literature' in Jewish Encyclopedia (1906) <http://www.jewishencyclopedia.com/articles/3374-blind-the-in-lawand-literature $>$ accessed 9 August 2016.

143 CA Amidar (n 4). 
Despite the abovementioned, I wish to note that in the circumstances of the case before us, I found no merit in the Applicant's claims as if the arbitration award should have been revoked following the arbitrator's unfortunate illness, which caused her to go blind. As the appeal itself notes, the arbitrator's unfortunate illness and the blindness she contracted as a result thereof were discovered only during the second phase of the arbitration proceeding, after the first arbitration award was delivered. However, contrary to the Applicant's claims as if the arbitrator was required to review many documents and schemes in order to decide the second part of the arbitration proceeding, similarly to the District Court, I also hold that in light of the advanced stage of the arbitration proceeding when the arbitrator's disease was discovered, there was no reason for the arbitrator not to continue her work and conclude her decision in the matter of damages. The reviewing of these documents was done, most probably, already during the initial stage of the arbitration proceeding, for which there is no dispute regarding the arbitrator's ability to fulfil her duties. ${ }^{144}$

As Justice Danziger states, the arbitrator was able to review the schemes and other evidence before she went blind, and therefore was fully capable of finishing the arbitration proceeding which she had begun; there was also no reason for the arbitrator not to use the help of the legal assistant, who simply read the documents to her. ${ }^{145}$ Justice Danziger chose to decide only the matter at hand, and did not allow for interpretations about the ability of blind people to fill judicial or quasi-judicial roles. The opinion of Justice Ayala Procaccia on the same judgment did little to fill in this gap, as she did not refer to the question of the arbitrator's blindness at all.

In light of this judgment, it is hard not to feel a sense of missed opportunity. A case such as this one, with the potential to recognise the capabilities of people with disabilities to assume key roles in Israeli society, does not often reach the Supreme Court. The justices could have easily rested on Judge Meshel's decision, which expanded on the issue beyond the specifics of the case and opened up a broader discussion regarding the relationship between disability and society.

The Supreme Court justices' concrete unwillingness to make a fundamental and direct statement regarding people with disabilities and the Israeli Equal Rights Law is part of a wider trend of evading discussions of disability, overlooking its importance as a barrier that stands at the heart of many cases. ${ }^{146}$ The path towards ibid.

146 Doron Dorfman, 'The Inaccessible Road to Motherhood-The Tragic Consequence of Not Having Reproductive Policies for Israelis with Disabilities' (2015) 30 Colum J Gender \& L 49, 82. 
achieving formal legal recognition of the rights of blind people and integrating them into the judicial sphere was blocked upon reaching the supreme legal authority in Israel. ${ }^{147}$ There is a long way to go before the rights and skills of people with disabilities are fully recognised, despite the fact that the Israeli Equal Rights Law was enacted almost twenty years ago.

Nevertheless, one meaningful statement can be extracted from the Supreme Court's judgment in the matter of Amidar $v$ Hai. Justice Eliezer Rivlin held a dissenting opinion, and stated in paragraph 15 of his judgment:

I agree with my colleague Justice Y. Danziger in the matter of the arbitrator's disease. I also believe that the stage in which the proceeding was at, and in fact at any stage, the arbitrator's disease had no influence on her ability to decide the arbitration. Neither of the Applicant's other claims constitute in my mind cause to intervene in the arbitration award. ${ }^{148}$

Justice Rivlin opined that, even if the arbitrator had gone blind before reviewing the evidence, this would not have been enough of a reason to disqualify her-that a blind person could serve as an arbitrator throughout all phases of the proceedings, including the evidence-hearing phase, despite her inability to form an impression from the witnesses' appearances. Therefore, it is nevertheless possible to extract an attentive statement on the issue at hand.

One can wonder why the Supreme Court refrained from making a fundamental statement that could help to end or at least reduce and undermine the marginalisation of people with disabilities from the workforce and from key positions in Israeli society. Lack of awareness and recourse to the medicalindividual models as well as mercy-based attitudes towards disability produce judicial rulings of this kind, and propagate injustice and discrimination against this group. Most likely, until a deeper perceptual change occurs among the entire population, and among judges in particular, we will be forced to read between the lines of judgments and hold on to small signs of progress.

About eighteen months after the Supreme Court's judgment, the case reached the courts for the fourth time. This time, Amidar petitioned the Tel Aviv District

147 Formal legal recognition is defined as a significant phase in making a right more accessible. It is the establishing moment in which a higher legal authority, such as the Supreme Court or the legislator, declares the existence of a right or the scope of the application of the equality principle. See Morton J Horwitz, 'Rights' (1988) 23 Harvard Civil Rights and Civil Liberties L Rev 393, 404. 
Court with the claim that the arbitrator should be relieved from her duties because, during the renewed hearings relating to the question of alleged damage caused to Amidar, she was being unfair and biased towards them. ${ }^{149}$ Ironically, these claims go against the metaphor of blind justice as impartial and objective, raising once again the puzzle of the Blind Justice Paradox. Even in this request, Amidar repeated its claims regarding the arbitrator's inability to deliberate the case due to her blindness. Judge Yehuda Zaft refused to consider the question of ability once more since it had already been deliberated in previous judgments. ${ }^{150}$ Amidar appealed the decision to the Supreme Court, before Justice Elyakim Rubinstein. ${ }^{151}$ In his 2011 decision, Justice Rubenstein referred to the question of the arbitrator's blindness in one paragraph at the end of his judgment: ${ }^{152}$

With regard to the Applicant's claim which relies on the arbitrator's visual impairment, I do not believe that it is worth commenting on, and best if it were not made at all, both in light of their dismissal in previous non-appealable decisions, and due to the arbitrator's dignity, which we are all obligated to maintain and insist thereon. Let us imagine a situation in which, God forbid, one of us loses his eyesight, but not his mental capacity; would it be right to marginalise him, and push him aside? 'That which is hateful to you, do not do to your fellow' said Hillel the Elder (Bablyonian Talmud, tractate Shabbat 31a). Our sages called a person who had lost his eyesight Sagi Nahor-great light-also in order to denote the virtues of a person who cannot see. Human history, from the Amora Rav Sheshet, to authors and creators of our time, is filled with examples of people with remarkable achievements despite their visual impairment. Thus, the great Egyptian author Taha Hussein, thus my former teacher at the Hebrew University, Prof. Haim Blanc, IDF disabled veteran from 1948 and a blind man, gifted linguist; and more recently the governor of the State of New York; also a judge at the US Court of Appeals for the Federal Circuit in Washington is a blind man. ${ }^{153} \mathrm{I}$ do not discount the technical difficulty of reviewing accounting documents etc. in the state of visual impairment, however it is Not in Heaven. ${ }^{154}$

Justice Rubenstein's concrete referral to the question of the arbitrator's blindness should be commended, since beforehand, the Supreme Court completely ignored

149 DC (TA) 48355-06-11 Amidar-National Co for Immigrant Housing Ltd v Hai (7 September 2011), Nevo Legal Database (by subscription) (Isr).

150 ibid para 7 (Zaft J).

151 CA Amidar 2011 (n 5).

152 ibid para 27.

153 Referring to Judge David Tatel.

154 CA Amidar 2011 (n 5). 
the issue. However, I believe that even this statement misses the great potential it could have had in describing the complexity of societal and legal attitudes towards blind persons and people with disabilities. In his judgment, Justice Rubenstein, like Judge Uri Goren, turns to the Hebrew Law as well as to his personal experiences and relationships in order to support his conclusion that 'a person who has lost his eyesight should not be marginalised and pushed aside. Surprisingly, Justice Rubenstein does not mention the Israeli Equal Rights Law at all, despite the fact that its underlying basic principle is recognition of 'the value of each person created in the image [of God], ${ }^{155}$ or the issue of the prohibition of employment discrimination. ${ }^{156}$ The lack of legal framing shows, once again, how disability is often not thought of as a matter of rights, but rather as a general act of solidarity (at best) or an issue of mercy and kindness (at worst). Although Justice Rubenstein mentions the human dignity principle, he does not do so in order to invoke the prohibition on discrimination against a person for his difference, a principle he exemplifies through the rule: ' $[\mathrm{t}]$ hat which is hateful to you, do not do to your fellow. He reaches the desired and correct result in this case, but in a way that differs from the one proposed by this article. The problem with the approach taken by Justice Rubenstein is that it ignores the legal criteria and tools developed to improve the lives of people with disabilities and thus inherently limits the progress that can be made in this regard.

The relatively new field of disability legal studies, to which this article contributes, is intended to deal with issues of precisely this kind. Its goal is to expose judges, lawyers and jurists to an alternative and progressive approach towards disability to be used when they deal with the numerous issues pertaining to the relations between people with disabilities and the legal sphere. I believe that Justice Rubenstein's welcomed judgment indicates the need for creating awareness of alternative models of disability in legislation, legal rulings and theories pertaining to society and the law's approach towards people with disabilities. ${ }^{157} \mathrm{I}$ am hopeful that this article and those that follow will help to expand this awareness of the field among the courts, jurists, and the public. This way we will all benefit from a collection of precedents that apply the principles of the social model, which may significantly advance the rights of people with disabilities in many societies.

Section 1 (basic principle) to the Israeli Equal Rights Law (n 113). ibid Section 8.

For a comprehensive and enthralling discussion regarding the importance of assimilating disability legal studies into the law faculties and the need to raise awareness of this field among jurists, see Kanter (n 10) 444-62. 


\section{Conclusion}

The image of the blind Icon of Justice has been a fixture in the Western world for hundreds of years. Nonetheless, not much has been written about the complexities and obstacles that stand in the way of placing actual blind judges on the bench. Nor has the Icon been used to represent a social struggle regarding disability rights.

The unique case of Amidar $v$ Hai represents a missed opportunity to challenge the traditional social construction concerning the abilities of blind persons, and people with disabilities in general, especially regarding their capability to assume key roles in society. The Israeli Supreme Court justices' way of dealing with the case before them, which avoided appealing to the Israeli Equal Rights Law and disability studies concepts, seems to be part of a wider trend I have addressed. The reallife examples of blind judges performing meticulous and complex judicial work stand as testimony to their abilities and the possibility of incorporating people with disabilities into judicial systems. I hope this article will serve as another brick in building the field of disability legal studies, and a reference for legal professionals encountering legal issues involving blindness and disability. 